\title{
Logic and Philosophy of Religion
}

\author{
Ricardo Sousa Silvestre $^{1}$ (D) Jean-Yvez Béziau ${ }^{2}$
}

Published online: 14 September 2017

(C) Springer Science+Business Media Dordrecht 2017

\begin{abstract}
This paper introduces a special issue on logic and philosophy of religion in this journal (Sophia). After discussing the role played by logic in the philosophy of religion along with classical developments, we present the basic motivation for this special issue accompanied by an exposition of its content.
\end{abstract}

Keywords Logic P Philosophy of religion - Arguments for and against the existence of God · Analysis of the religious concepts · World Congress on Logic and Religion

From a historical point of view, logic has been a constant companion of philosophical reflections about religion. Arguments for and against the existence of God have been proposed and subjected to logical analysis in different periods of the history of philosophy. A good example of this are the several versions of the ontological argument which appeared since Anselm's seminal work, the Proslogion, in the eleventh century, as well as the several kinds of logical scrutiny which they have been subjected to. Some of the greatest pre-twentieth century philosophers, including Descartes, Leibniz, Spinoza, and Kant, have either proposed or analyzed ontological arguments.

Ontological arguments are of course just one type of theist arguments, albeit the best exemplar of a priori arguments for the existence of God. Other (kinds of) arguments of historical importance are cosmological arguments, moral arguments, teleological and design arguments, arguments from miracles, etc.

From the perspective of atheist arguments, the problem of evil occupies a prominent place. Names such as Epicurus, Aquinas, Leibniz, Hume, and Kant have addressed it.

Ricardo Sousa Silvestre

ricardoss@ufcg.edu.br; http://www.ch.ufcg.edu.br/ silvestre.uacs

Jean-Yvez Béziau

jyb@uni-log.org

1 Federal University of Campina Grande, R. Aprígio Veloso, 882 - Bodocongó, Campina Grande, PB 58429-900, Brazil

2 Federal University of Rio de Janeiro, Av. Pedro Calmon 550, Rio de Janeiro, RJ 21941-901, Brazil 
For instance, Hume's Dialogues Concerning Natural Religion, from the eighteenth century, remains one of the best pre-twentieth century expositions and analyses of the problem of evil, even anticipating some of the tenets which would guide the contemporary debate on evil and God. Although many times put as an argument against the existence of God, the problem of evil has been traditionally described as an inconsistency, either logical or evidential, between the existence of an omnipotent, omniscient, and wholly good being and the existence of evil and suffering in our world. Even though in most cases equivalents, the latter way of presenting the problem illustrates the real point of the problem, which is to challenge the rationality of theistic belief.

In fact, arguments for and against the existence of God are the most traditional way to conduct the debate on the rationality of theistic belief, also called, as a field, the epistemology of religion. ${ }^{1}$ The other great area of the philosophy of religion is the analysis of the concept of God. ${ }^{2}$ There also, logic has had a role to play. Take perfect being theology, for example. Basically, perfect being theology consists in, from some definition of God as a maximally perfect being, logically deriving several of God's properties or perfections, including his existence - that is the ontological argument-, uniqueness, omniscience, omnipotence, moral perfection, omnipresence, eternality, impassibility, and simplicity. Anselm was the first one to do that; Descartes, Spinoza, and Leibniz have engaged in the same kind of project. Leibniz was the first to not take for granted that all perfections are compossible, bringing into scene the notion of consistence. Nowadays, the consistency of divine properties, taken one by one or collectively, is one of the main themes in this field of philosophy of religion.

All this does not mean that logic as a field had played a strong role in the philosophy of religion. To start with, there is a distinction between the use of logic as an indispensable component of any rational discourse and the use of tools and results of the field we call logic. For instance, one thing is to propose an argument and even analyze it (perhaps identifying premises and hidden presuppositions and conclusion and seeing to what extent the former entails the latter) using plain language and intuitive reasoning. Another thing is to do that with the help of a logical language and a formal theory of inference or to make reference to pertinent results of modern logic.

This distinction becomes stronger when we consider the process of mathematization which logic was subject to in the end of the nineteenth century and beginning of the twentieth century. At the same time that this process was responsible for an extraordinary growth in the field, it also produced divergent views concerning the role of logic in philosophy. Referring to formalization in a broader sense, Sven Hansson writes as follows:

Few issues in philosophical style and methodology are so controversial among philosophers as formalization. Some philosophers consider texts that make use of logical or mathematical notation as non-philosophical and not worth reading, whereas others consider non-formal treatments as-at best-useful preparations for the real work to be done in a formal language. (Hansson 2000, p. 162)

\footnotetext{
${ }^{1}$ Pragmatic arguments such as Pascal's wager, for example, also address the issue of the rationality of theism but without trying to reach the conclusion about God's existence.

${ }^{2}$ We are here purposefully neglecting other fields of the philosophy of religion such as religion and science, religion and ethics, Wittgensteinian philosophy of religion, comparative philosophy of religion, and so on and so forth.
} 
As far as the analytic tradition is concerned, such a statement might certainly sound odd; it is well known that modern logic played a role in the rising and consolidation of analytic philosophy. For instance, the views of Russell and Carnap on the role of logic and logical analysis in philosophy are still paradigmatic. While Russell famously identified philosophy with logic - according to him, 'Every philosophical problem, when it is subjected to the necessary analysis and justification, is found either to be not really philosophical at all, or else to be, in the sense in which we are using the word, logical.' (Russell 1914, p. 14)—, Carnap's project of conceptual analysis had formal logic as an indispensable element (Carnap 1950, p. 1-18).

This was naturally reflected in the work of many analytic philosophers of religion. Alvin Plantinga, William Rowe, Richard Swinburne, and Peter Van Inwagen, just to mention a few, all have in some way or another incorporated results and tools of logic in their works. There have also been heavier uses, we might say, of logic in the philosophy of religion which would fit better Hansson's quotation; for example, there have been in the past decades quite a good number of attempts to formalize, using specific logical languages and inferential theories, several kinds of ontological arguments. ${ }^{3}$

Despite this, and contrasting with other areas of philosophy such as epistemology and ethics, we can safely say that there is not a logical tradition in the philosophy of religion. This is reflected by the absence of textbooks on the subject ${ }^{4}$ as well as by the lack of mention of philosophy of religion in the recent work on formalization in philosophy. ${ }^{5}$ Going through another path, there is not a close connection from the professional academic point of view between logic and philosophy of religion; there are no regular seminars or congresses or societies or specialized journals dedicated to the topic.

Such a state of affairs is certainly regrettable, for if we take a very straightforward characterization of logic and the two main areas of philosophy of religion we have mentioned earlier, the exact opposite would be expected. From one side, logic is a theory of inference. We therefore would expect it to have been massively used in the construction and appraisal of arguments for and against the existence of God. From the other side, logic is a theory of representation. We therefore would expect it to have been used in the analysis of key religious concepts, such as the concept of God. By this we do not mean that the connection of logic and philosophy of religion we are talking about must necessarily go through formalization. Logic is a broad subject matter, and its possible contributions to any philosophical field certainly go beyond the use of a formal language and an inference theory.

A first exception to this occurred in 2015, when the 1st World Congress on Logic and Religion took place in João Pessoa, Brazil. It was a forum where logicians, philosophers, theologians, mathematicians, and computer scientists from all over the

\footnotetext{
${ }^{3}$ Adams (1971), Barnes (1972), Oppenheimer and Zalta (1991), Klima (2000), and Sobel (2004) are examples of this.

${ }^{4}$ Sobel's book (2004) could perhaps be one of the few exceptions to that, although he does not present the work of a field, but mostly his own versions of several famous arguments in the philosophy of religion.

${ }^{5}$ While Timothy Williamson (2017), for instance, mentions many paradigmatic instances of formalization in ethics, epistemology, and philosophy of language, no word is said about philosophy or religion. This pattern is repeated in the still small but growing literature on formalization in philosophy [see Hansson (2000), Van Benthem (2006), Horsten and Douven (2008), Horsten and Pettigrew (2011), and Williamson (2017), for example].
} 
world gathered to discuss the latest developments in logic and religion. Besides this international and interdisciplinary flavor, the 1st World Congress on Logic and Religion was also interreligious: there were talks about all great religious traditions of the world. ${ }^{6}$ The approaches to logic were also varied, going from 'heavy' uses of mathematical logic to more 'diluted' and analytical approaches.

This special issue contains some of the papers delivered at the 1st World Congress on Logic and Religion. It is in fact the second publication resulting from the event. The first one was the special issue on Logic and Religion of Logica Universalis (Beziau and Silvestre, 2017), which focused on more technical contributions and tried to be balanced regarding world religious traditions. Also, the styles of the contributions were broad, not restrained by the philosophical approach to religion we are emphasizing here, thus the title "Special Issue on Logic and Religion." There were two papers related to Hinduism and Indian philosophy (Bilimoria 2017; Silvestre, 2017a); one dealing with logic in the Islamic world (Akrami 2017); and four dealing with the ontological argument for the existence of God, focusing on Anselm's Christian motivated formulation (Archambaut 2017; Desclés 2017), Leibniz's formulation (Lenzen 2017), and the contemporary formulation of Gödel (Benzmüller et al., 2017)

This Sophia special issue focuses on the connections between logic from a broader perspective and philosophy of religion proper. The second and third articles are about theist arguments. In the second paper, Jamie Watson (2017) shows how specialized and localized argument analysis should or need to be. He deals with the kalām cosmological argument or, more specifically, with a criticism against an argument for the second premise of William Craig's version of the kalām argument. According to this criticism, the argument (not Craig's argument, but the argument for its second premise) illicitly assumes a finite starting point for a series of past temporal events, thereby begging the question against opponents. One of Watson's basic points is that there is an ambiguity in the argument which the criticism rests on. Formulating a new, disambiguated argument, which he does, is then a way out of the criticism. The reward in the case which his new argument is sound is proportional to the specialized nature of the enterprise he engages in: as he says at the end of the text, there would be in this case one fewer reason to doubt the plausibility of the kalām argument's conclusion (for we would have found a reasonable support for at least one of its premises).

The third paper, by Cassiano Rodrigues (2017), deals with a theist argument by the famous nineteenth century logician Charles Peirce. One of the peculiarities of this argument is that it is not an argument for the existence of God, but for its reality. Another peculiarity is that the argument relies on a specific non-reflective mental activity which Peirce calls musement. He claims that in musement, we can achieve a kind of perception of the intertwinement of the three universes of experience: feeling, brute fact, and reason, therefore being in the sort of mental state required for us to believe in the reality of God. Rodrigues' main contribution rests on analyzing in deepness the notion of musement and the role it plays not only in the argument itself, but also in Peirce's more general, metaphysical, and epistemological views. By analyzing the argument along with a more general philosophical framework, he follows a different path from the overspecialized approach the previous paper instantiates.

\footnotetext{
$\overline{{ }^{6} \text { See http://www.uni-log.org/logic-and-religion-1.html. }}$
} 
The next two articles deal with the prince of atheist arguments: the problem of evil. More specifically, they deal with one of the central movements used by theists to respond to the problem of God and evil: the project of theodicy. Thus, although dealing indirectly with the argument, these papers are in fact contributions to the field of conceptual analysis inside the philosophy of religion.

The fourth article, by Ondrej Beran (2017), discusses the approach to the problem of evil employed of D. Z. Phillips. Phillips follows what many philosophers would call a Wittgensteinian approach to the philosophy of religion. It is therefore not surprising that his contribution to the problem of evil is strongly centered on the analysis of the concepts involved. He criticizes the concepts of God's omnipotence and wholly goodness, and, perhaps more importantly, he lays down quite interesting arguments against the idea that the evil and good we find in our world can be measured and compared against each other, which is a key idea in many theodicies. Besides presenting Phillips ideas on theodicy and the problem of evil, Beran points out some important flaws in them. A very important one has to do with a key movement we find in Phillips arguments: his use of what he calls 'our religious language.' Many times he complains that the theodicist's use of the notions of omnipotence and wholly goodness does not fit into our religious language. But who is this 'us' on behalf of whom Phillips speaks? He seems to uncritically assume the existence of something like a worldly representative community of religious practitioners whose language does not accord with some key uses of the terms made by theodicists. But this is extremely artificial, to say the least.

In the fifth article, Ricardo Silvestre (2017) engages in conceptual analysis in a much more explicit way. Following the basic lines of Rudolf Carnap's project of conceptual explanation, he proposes to analyze the very concept of theodicy. To Carnap, a conceptual explanation is an attempt to transform a given more or less inexact concept, the explicandum, into a more precise and exact one, the explicatum. Silvestre's explicandum is the concept of theodicy as used by analytic philosophers of religion; he thus extensively quotes contemporary views on the notion of theodicy. From this, he extracts, in a sense, several conditions which according to these philosophers a theodicy should satisfy. Finally, he shows how from these conditions we can get several different notions of theodicy, thus ending up with not only one explicatum but quite a great variety of theodical notions. Although Silvestre follows what he terms a semi-formal approach, in an important sense, his contribution belongs to what we have named above as 'formalization in philosophy.'

The next two articles move to the analysis of key theist concepts proper. The sixth paper, by Errin Clark (2017), deals with one of the most important and at same time most problematic divine properties: omnipotence. Roughly understood, omnipotence means the power of doing anything. If, therefore, there is an omnipotent being, it is necessary that he can do anything, like creating a stone that he cannot lift. But if this is so, it is possible that there is something he cannot do, namely to lift the stone; he therefore is not omnipotent. On the other hand, if it is possible that he cannot create such a stone, then he is not omnipotent either. Consequently, the very notion of omnipotence is incoherent, which leads us to the conclusion that there cannot a priori exist any being which instantiates this property.

Naturally, such a conclusion depends on the meaning of the terms used. By saying that omnipotence means the power of doing anything, we mean the power of 
performing any task or the power of realizing any state of affairs. And what exactly does having the power to do either mean? Here, Clark tries to show that when we look seriously at Thomas Aquinas' views on logic, being, and power, these and other pertinent questions are answered in such a way that there is no more contradiction in the notion of an omnipotent being. For instance, considering either 'a stone its maker cannot lift' (that is, choosing the power of performing any task) or 'creating a stone its maker cannot lift' (that is, choosing the power of realizing any state of affairs), 'its maker' is supposed to indicate God. Since for Thomas God's essence contains all powers and perfections from which the powers and perfections of created beings originate as their source, there cannot be any perfections in a created being that do not already exist (preeminently) in God. Therefore, neither statement can succeed in indicating anything possibly real.

In the seventh paper, Daniel Molto (2017) presents an instantiation of the relations that might be between philosophical theology and formal logic. He deals with the use of formal logic in the clarification of religious concepts, in this case the Christian concept of Trinity. More than a clarification, however, the paper deals with the attempt to solve a contradiction involved in this concept. The doctrine of Trinity, as it is many times called, involves the idea that God exists in three persons. In order to have content, these three persons of the Trinity must be somehow different from each other; but then, we have not one God, but three Gods. But according to one of the most basic assumptions of Christianity, God is one; therefore, if God exists in three persons, they must be identical to each other. We thus have a contradiction.

This conclusion depends on the way we see the relation of identity: it basically assumes an interpretation of the expression 'there is but one God' alike to Russell's theory of definitive descriptions: for some $y$, $y$ is God, and for any $z$, if $z$ is God, $z$ is the same as y. According to Peter Geach, however, that was not the way Aquinas saw it: According to him, the sameness involved here must be specified by some general term signifying a form of nature. Therefore, the correct way to represent the expression would be as follows: for some $\mathrm{y}, \mathrm{y}$ is God, and for any $\mathrm{z}$, if $\mathrm{z}$ is God, $\mathrm{z}$ is the same God as y, which would block the conclusion that the three persons of the trinity are identical (in all respects) to each other. Taking up this idea, Molto defends that the so-called strong theory of relative identity is the best solution to the problem of Trinity. Besides, presenting thus the problem, he elaborates what he takes to be the most pressing objection to this account of the Trinity, namely that it cannot be supplemented with a coherent model-theoretic semantics, coming up with a proposed solution to it.

These are the papers related to the 1st World Congress on Logic and Religion. Besides them, this issue contains seven more original papers not connected with the aforementioned event but still related to the main theme of the issue-God's Existence and the Kantian Formula of Humanity by John Lemos; A Radical Solution to the Problem of Evil by Gerald K. Harrison; Free Will Theodicies for Theological Determinists by T. Ryan Byerly; Kant on the Epistemology of Indirect Mystical Experience by Ayon Maharaj; Imagine Being a Preta: Early Indian Yogācāra Approaches to Intersubjectivity by Roy Tzohar; An Introduction to the Daśaślokī of Śamkara and Its Commentary Siddhāntabindu by Madhusūdana Sarasvatī by Niranjan Saha; and Skeptical Theism Remains Refuted: a Reply to Perrine by David Kyle Johnson- two book reviews and an obituary. 


\section{References}

Adams, R. (1971). The logical structure of Anselm's arguments. The Philosophical Review, 80, $28-54$.

Akrami, M. From logic in Islam to Islamic logic.: 61-83, 2017.

Archambaut, J. (2017). Monotonic and non-monotonic embeddings of Anselm's proof. Logica Universalis, $11,234-236$.

Barnes, J. (1972). The ontological argument. London: Macmillan.

Baziau, J-Y; Silvestre, R. (eds.) Special Issue on Logic and Religion. Logica Universalis, volume 11, Issue 1, 2017.

Benzmüller, C., Weber, L., \& Paleo, B. W. (2017). Computer-assisted analysis of the Anderson-Hájek ontological controversy. Logica Universalis, 11, 53-54.

Beran, O. (2017). Misunderstanding the Talk(s) of the Divine: Theodicy in the Wittgensteinian Tradition. Sophia 56. doi:10.1007/s11841-017-0600-2.

Bilimoria, P. (2017). Thinking negation in early Hinduism and classical Indian philosophy. Logica Universalis, 11, 115-139.

Carnap, R. (1950). Logical foundations of probability. Chicago: University of Chicago Press.

Clark, E. (2017). Thomas Aquinas on Logic, Being, and Power, and Contemporary Problems for Divine Omnipotence. Sophia 56. doi:10.1007/s11841-017-0604-y.

Desclés, J.-P. (2017). A logical analysis of the Anselm's Unum argumentum (from Proslogion). Logica Universalis, 11, 115-148.

Hansson, S. (2000). Formalization in philosophy. The Bulletin of Symbolic Logic, 6, 162-175.

Horsten, L., \& Douven, I. (2008). Formal methods in the philosophy of science. Studia Logica, 89, 151-162.

Horsten, L., \& Pettigrew, R. (2011). Mathematical methods in philosophy. In L. Horsten (Ed.), The continuum companion to philosophical logic (pp. 14-26). London: Continuum Publishing.

Klima, G. (2000). Saint Anselm's proof: A problem of reference, intentional identity and mutual understanding. In G. Holmström-Hintikka (Ed.), Medieval philosophy and modern times (pp. 69-87). Dordrecht: Kluwer.

Lenzen, W. (2017). Leibniz's ontological proof of the existence of god and the problem of impossible objects. Logica Universalis, 11, 85-104.

Molto, D. (2017). The Logical Problem of the Trinity and the Strong Theory of Relative Identity. Sophia 56. doi:10.1007/s11841-017-0612-y.

Oppenheimer, P., \& Zalta, E. (1991). On the logic of the ontological argument. In J. Tomblin (Ed.), Philosophical perspectives 5: The philosophy of religion. Atascadero: Ridgview Press.

Rodrigues, C. (2017). The vagueness of the muse - the logic of peirce's humble argument for the reality of God. Sophia 56. doi:10.1007/s11841-017-0610-0.

Russell, B. (1914). Our knowledge of the external world. Chicago and London: The Open Court Publishing Company.

Silvestre, R. (2017a). Karma theory, determinism, fatalism and freedom of will. Logica Universalis, 11, 35-60.

Silvestre, R. (2017b). On the concept of theodicy. Sophia 56. doi:10.1007/s11841-017-0609-6.

Sobel, J. (2004). Logic and theism. New York: Cambridge University Press.

van Benthem, J. (2006). Logic in philosophy. In D. Jacquette (Ed.), Philosophy of logic (pp. 65-100). Amsterdam: North-Holland.

Watson, J. (2017). The End of Eternity. Sophia 56. doi:10.1007/s11841-017-0590-0.

Williamson, T. (2017). Model-Building in Philosophy. In: Blackford, R. and Broderick, D. (eds.) Philosophy's Future: The Problem of Philosophical Progress, Oxford: Wiley-Blackwell. doi:10.1002/9781119210115. 